\title{
CORPORATE SOCIAL REPORTING AS A BUSINESS IMPROVEMENT TOOL
}

\author{
Anna Bagieńska \\ Faculty of Engineering Management, Bialystok University of Technology, \\ Tarasiuka 2 Str., 16-001 Bialystok, Poland \\ E-mail: a.bagienska@pb.edu.pl
}

\begin{abstract}
Corporate Social Responsibility (CSR) provides the contribution of business to the implementation of sustainable development enabling to achieve a balance between business effectiveness, as well as the social interests and environmental protection. The CSR report presents the results of economic and social activities of enterprise. The CSR report creates the possibility of evaluation of the enterprise achievements in the context of financial and non-financial expectations of stakeholders different from financial capital providers. The aim of the paper is to present the role and importance of CSR reporting based on international standards and guidelines as well as to identify the main evaluation criteria. The analysis of the contents of the CSR reports submitted to the Competition CSR Report in the years of 2011-2016 shows what tools and key performance indicators are used. On the basis of the research results, the method of assessment of the CSR activities were proposed.
\end{abstract}

Keywords: Corporate Social Responsibility reporting, non-financial information.

JEL Classification: M14, M41, M21.

\section{Introduction}

Social responsibility of business is defined as a voluntarily employed strategy of enterprises comprising social, ethical and ecological aspects of operation in commercial activities and in contacts with stakeholders (Green Paper, 2001). According to the conception of sustained development, an enterprise should aim at achieving broadly understood benefits for all stakeholders, local communities and the environment, not only focusing on only economic profit of a company (Urbaniec, 2015). Corporate Social Responsibility (CSR) is a bidirectional open system, on one hand, directed towards signals from the society, on the other, openly and publicly revealing conducted activities. The Corporate Social Responsibility reporting is a tool which enables informing stakeholders about the enterprise responsibility. Undertaking CSR and the Corporate Social Responsibility reporting are optional initiatives of an enterprise. The EU Non-Financial Reporting Directive (2014/95/EU) obliges only big public interest companies to report on non-financial information (e.g human rights, employee-related matters, environment, anti-corruption) as a supplement to an annual financial report. For other firms, reporting on social responsibility is not obligatory, but it is advisable with a view to presenting stakeholders a comprehensive picture of the enterprise activity.
Non-Financial Reporting Directive is the most important EU regulation which to supports the CSR reporting.

International Integrated Reporting Cancel also encourages preparing an integrated report combining financial data with CSR data. Other tools supporting CSR reporting as a separate report are mainly the guidelines of the Global Reporting Initiative and the ISO26000 norm regarding social responsibility.

So far, there have been no homogeneous and precise rules of non-financial reporting and reporting on socially responsible activities. Therefore, preparing the of a CSR report belongs to the most serious accounting tasks for the enterprises. The aim of the paper is to present the role and importance of the CSR reporting based on international standards and guidelines as well as to identify the main evaluation criteria.

\section{Corporate social responsibility and reporting}

Corporate social responsibility is a significant factor in a company's competitiveness. CSR consists in modeling the relation of an enterprise with internal and external stakeholders (Skrzypek, 2015). In Social Responsibilities of the Businessman (Bowen, 1953) first covered the relation of 
companies and society (Carrol, 1979; Wartick \& Cochran, 1985; Skrzypek, 2015). The scholar argues that firms have to understand the role of business ethics to improve their performance in the long-term (Wang, 2015).

Long-term consumer-employee trust can be created by socially responsible firms so that it could function as a foundation for sustainable business models. As a consequence, it facilities creating condition in which a given company can grow and develop its innovation (H. Zhao, F. Zhao, \& Kwon, 2018).

Nowadays, stakeholders play a very important role, especially in the decision-making process in the enterprises. They set enterprises not only economic and social demands, but also ecological ones (Wagner, 2010; Urbaniec, 2015). Noticing the stakeholders' needs is an indispensable element of modern enterprises activity (Urbaniec, 2015). Building a relation with the enterprise stakeholders is one of the main aims of the CSR activities. Due to the increasing popularity of CSR, it is the object of wide-scope analyses conducted by practitioners and theoreticians (Weber, 2008). Scientists investigate CSR-related aspects in terms of stakeholder relation and communication (Basu \& Palazzo, 2008), the impact of stakeholder relations on corporate sustainability (Choi \& Wang, 2009), CSR awareness in the group of stakeholders and its relation with corporate investment, corporate financial results, and employee loyalty (Sen, Bhattacharya, \& Korschun, 2006).

Cheng, Lin, and Wong (2016) emphasize that previous company performance has an important positive influence on the publication of the standalone CSR reports. In the same vein, the current CSR reports are related with the performance to be achieved in the next period. These researches also observe that corporate donations are bound to have a positive effect on the financial and non-financial performance of the company in the following year. These results corroborate that CSR is an appropriate practice to be implemented even in a developing country (Cheng et al., 2016).

Feng, Wang, and Kreuze (2017) investigate how the relationship between a company involvement in CSR and the firm financial performance varies in different branches of industry and CSR categories. According to these scholars, relation of the general CSR activities and the enterprise performance can be described as heterogeneous. CSR has important advantageous implications for companies from most, analyzed industries, but it should be emphasized that not for all of them. The comparison of the performance implications of CSR activities in particular stakeholder groups shows that, different CSR kinds have various effects on financial results of companies in given industry sectors (Feng et al., 2017).

The development of research on CSR is also attested by the fact that CSR 2 and CSP have been distinguished (Valor 2005):

- CSR2 (Corporate Social Responsiveness) - understood as a social reactivity of business, i.e. an active attitude of an enterprise to CSR and relating social activity with strategic management,

- CSP - (Corporate Social Performance) - social achievements of business, i.e. an attempt to create a practical approach to CSR, which - from managers perspective - would facilitate managing CSR and would enable measuring the effects of this activity (Skrzypek, 2015).

The notion of social responsibility of business includes two dimensions (Zapłata \& Kaźmierczak, 2011):

- internal: managing human resources, ethical programs for employees, employees development programs, managing environmental protection, responsibility for product,

- external: managing the supply chain, sponsoring and subsidies, cooperation with non-government organizations and other local partners, educational programs aiming at increasing awareness of CSR, activity for broadly understood natural environment.

It should be emphasized that the CSR concept presents framework conditions for enterprises with a view to voluntary integrating social and ecological aspects in their business activity and in the mutual dependences between stakeholders (Litfin, Meeh-Bunse, Luer, \& Teckert, 2017). Innovation may function as a significant encouragement for corporate sustainability management and accounting practices used in a given company to support sustainable development and sustainable economic grow (Kendiukhov \& Tvaronavičienè, 2017; Schaltegger, Etxeberria, \& Ortas, 2017; Komarova, Lonska, Lavrinenko, \& Menshikov, 2017).

If enterprises have a better CSR ratings, they may have a sustainable competitive advantage because such firms attract better and more qualified employees than CSR lower-rated companies (Greening \& Turban, 2000; Skrzypek, 2010; Wang, 2015). Therefore, to continue sustainable 
development, and, to achieve a reputation in a highly competitive market, more and more entities decide to publish their CSR disclosures and CSR reports (Wang, 2015). All enterprises attempt to share important information at the right time and through the most convenient means to meet the needs of its stakeholders and employees (Raudeliūnienè, Meidutè-Kavaliauskienè, \& Vileikis, 2016)

Corporate Social Responsibility reporting can be defined as a way of providing external and internal stakeholders with the information on the enterprise results concerning economic, social and environmental aspects. Reporting on effectiveness of social involvement of companies is the basis of the decision-making process, since it allows for a comprehensive evaluation of activity, the choice of priorities and undertaking activities to realize them.

Corporate sustainability demands integrative measurement and sustainability management with much less emphasis on implementation of its individual tools in the organization. Different aspects, such as: performance assessment, management accounting, supply chain management, controlling and reporting, are understood and used in multiple ways, but they tend to function in isolation. Therefore, is suggested that it is worth introducing a general, integrated framework of sustainability measurement, control and reporting (Jia, Mahdiraji, Govindan, \& Meidute, 2013; Maas, Schaltegger, \& Crutzen, 2016). The company should present its communication with stakeholders in an aggregated form and highlight individual, especially relevant stakeholder-relationships in the Environmental, Social \& Governance report or via the Internet (EFFAS, 2014).

\section{Guidelines and norm of CRS reporting}

Companies should implement CSR policies into strategic objectives in a meaningful and logical manner, providing a measuring system that will allow for objective assessing benefits during their implementation (Knezevic, 2016). Reporting on non-financial data is more difficult because of the specific character of non-financial information, mainly:

- subjectivity;

- difficulty to measure the effectiveness of activities included in the report;

- no possibility to compare data;

- difficulty to define the limits of completeness and legibility;
- risk of using boiler-plate templates, regardless of the environment in which a company operates;

- prospectiveness and the ensuing uncertainty.

The fact that there is no mandatory format of presenting non-financial data and no clearly defined conditions and methods of their verification creates the risk of presenting unreliable non-financial information to stakeholders (ZysnarskaDworczak, 2017).

Since reporting on social responsibility is optional, the enterprising which decide to prepare a CSR report are free to choose its form and the information to be included in it. For social reporting, this freedom causes that the evaluation and comparison the level of social responsibility of individual organizations is a difficult task. Therefore, in order to unify the social reporting process, standards of social responsibility reporting are created (Wołczek, 2013). The most common tools of CSR reporting which attest conducting business in a responsible way include:

- Global Reporting Initiative guidelines (GRI), updated in 2013,

- OECD guidelines for multinational enterprises (OECD Guidelines for Multinational

- Enterprises),

- UN Global Compact guidelines (United Nations Global Compact Principles),

- responsible investment rules (Guide to Responsible Investment - PRI),

- ISO 26000 norm concerning social responsibility (Guidance on Social Responsibility),

- SA 8000 norm (Social Accountability 8000 ),

- AA 1000 AccountAbility Principles Standard prepared as a result of dialogue with stakeholders and in cooperation with experts (Adamczyk, 2013).

The GRI guidelines, the most widely used reporting standards, assume that reporting is done at two levels: core (organization profile, stakeholders' involvement and management) and comprehensive (strategy and ethics); additionally, they allow for reporting on the information from a broader perspective, including the supply chain (GRI, 2013). The guidelines concern three categories: economic ratios, environmental ratios, social ratios (comprising four areas: employment practices and decent work, observing human rights, society, product responsibility. 
According to the GRI guidelines, the preparing of social reports should be guided by the following principles:

- relevance - the information included in the report should include the issues and ratios which reflect important economic and social influence of the organization as well as its influence on the natural environment, comprising also the matters which may have an important influence on the stakeholders' evaluations and decisions;

- including stakeholders - the reporting organization should define its stakeholders and explain in the report in which way it reacted to their justified expectations and interests;

- the context of sustained development the report should present the results of the organization in a broader context of sustained development;

- completeness - the issues and ratios included in the report and thus considered to be important as well as the defined scope of the report should be sufficient for showing relevant economic and social influence and the impact on the natural environment of the reporting organization and enable stakeholders to evaluate its results in the reporting period;

- the rules concerning ensuring high quality of report - balance, comparability, precision, timeliness, transparency and credibility (Mikulska \& Michalczuk, 2014).

The OECD Guidelines for Multinational Enterprises and ISO 26000 Guidance on social responsibility aim to promote responsible practices in organizations. Both instruments provide guidance for companies in the fields of labor practices, human rights, the environment, economic viability aspects, fair operating practices, community involvement, consumer interest, and other areas of sustainable development (ISO 26000 and OECD Guidelines Practical overview of the linkages 2017). The ISO 26000 norm is one of the three documents recommended by the European Commission to European enterprises for social responsibility implementation and comprises all organizations - public, private and non-profit, irrespective of their size and location. It includes the guidelines concerning social responsibility, is of advisory character and makes it easier for the organizations to operate in a socially responsible way. It should constitute an element of strategy reflected in the organization members' responsibilities and it ought to influence the decision-making process (Skrzypek, 2015; ISO 26000 and IRR). The OECD Guidelines as well as ISO 26000 foster promoting sustainable development. ISO 26000 underlines that a main goal of a company is to maximally support sustainable development, while the OECD guidelines highlight the positive input that multinational enterprises may have in economic, environmental and social development and which may reduce the negative effects.

The AA1000 AccountAbility Principles Standard (2008) (which is being revised to be made public by mid-2018) is an internationally binding, rules-oriented framework used by enterprises irrespective of their sizes, to recognize, underline, measure and correspond to sustainability in an inclusive and accountable way.

The aim of AA 1000 standard is to combine social and ethical issues of strategic management of the organization. It focuses on organization stakeholders, the necessity to include their needs and to involve them in the organization activity. The AA 1000 norm constitutes supports for each company, because the area of stakeholders is complex and a complete identification and inclusion of varied expectations and involvement are challenging for every organization. AA 1000 offers tools which can be useful because of the requirements of the international standard of GRI reporting, from which results the necessity of documenting the process of involving stakeholders in the reporting process.

The AA 1000 standards distinguish five main stages of managing the relations with stakeholders: planning, describing the responsibility rules, conducting the audit and preparing a report, implementation - enhancing the process, cooperating with stakeholders - groups related to the organization (clients, suppliers etc.).

The SA 8000 norm provides the standard based on international human rights and labor law. SA 8000 is a standard describing minimal requirements in the following areas: child labor, forced labor, health and safety, freedom of association and the right to collective negotiations, discrimination, disciplinary penalty, working hours, remuneration, management systems. Unlike ISO 26000, the SA 8000 norm constitutes the certification basis. Obtaining a certificate involves the enterprise being audited by a unit accredited by SAI (Social Accountability International). What differs SA 8000 from ISO 26000 is 
that the SA 8000 norm focuses on work conditions and disregards important issues related to clients and investors. According to the norm in question, the system of social responsibility management may be connected with other areas of management. The requirements of the norm are universal and may be implemented in each organization irrespective of its size, location and the sector of operation (Wróbel, 2016). Despite the development of numerous methods and tools the measurement of CSR is still a big challenge (Lulewicz-Sas, 2015).

\section{Research methods}

At the first stage of the research study, one will conduct the analysis of the Corporate Social Responsibility reporting in Europe and in the world on the basis of the latest results of KPMG research. It will be followed by the analysis of the contents of the CSR reports submitted to the Competition CSR Report in Poland in the period of 2011-2016. The aim of the research study is to answer the following questions:

1. How does the Corporate Social Responsibility reporting develop in w Europe and in the world?

2. In which way do the biggest companies report CRS? Do they do it as a separate report, including the information in the financial report, or preparing an integrated report?

3. What international standards, guidelines, tools and key performance indicators are used in the Corporate Social Responsibility reporting process?

As for the methodological approach adopted for purpose of the present study, three methods form the basis for the analysis: the content analysis of the social responsibility reports of the researched companies, morphological analysis, and the descriptive analysis. To analyze the CRS reports, one prepared the coding structure, focused on identifying the information regarding of implemented reporting tools and key performance indicators in the CSR report (Bagieńska, 2017). The research study comprises 305 CSR reports of Polish companies in the years of 2011-2017 published on-line by rejestrraportow.pl and raportyspoleczne.pl. 40 of them took part in the Competition "CSR report 2017".

\section{The development and practices of the Corporate Social Responsibility reporting}

On a global scale, the Corporate Social Responsibility reporting is an important and dynamically developing area. In 2017, the most actively reporting regions include: Americas (83\%) Asia Pacific (78\%) and Europe (77\%) (KPMG, 2017). In Eastern Europe the reporting rate is constantly relatively low reaching the level of 65 percent, in spite of a rise of 4 percentage points observed since 2015 (for comparison, in Western Europe, it amounts to $82 \%$ ). The countries located in this part of Europe are perhaps reducing the distance to the rest of the region, but it has to be admitted than they need time to do so. Undeniably, it will still last longer until the European Directive on Non-Financial Reporting is completely felt. According to the KPMG research, the highest $\mathrm{CR}$ reporting ratios in the world are observed for Japan, India, Malaysia and Taiwan (KPMG, 2017).

The CSR reporting is becoming a main trend, especially among big companies. In the period of the past18 years, there has been an immense increase of the number of companies reporting CSR. In 1999, 35\% firms from the G250 group reported CSR, while in 2017 - as many as $93 \%$. In 1999 , 100 of the biggest companies from each of the 49 countries (N4900) reported CSR in $24 \%$, and in 2017 - in 75\%. (KPMG, 2017) (Figure 1).

The CSR reporting trend used by G250 is similar to a logarithmic function, while the reporting trend of 100 biggest companies from each country is rather of linear character.

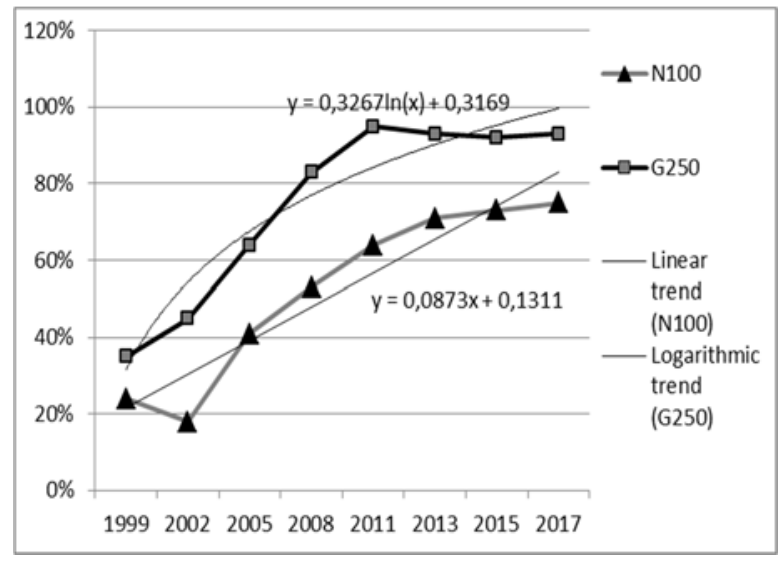

Figure 1. Growth in global CR reporting since 1999 with trend function (source: prepared on the basis of KPMG, 2017)

The research studies conducted by KPMG show that social responsibility reporting is a com- 
monly used practice in business, undertaken by almost three quarters of the companies researched in 2017 (KPMG, 2017).

In 2017, the companies most often include the CRS information in their annual financial report: $78 \%$ enterprises from the G250 group and $60 \%$ from N100. Integrated reporting is increasing, but it is doing so slowly. In $2017,14 \%$ of reporting enterprises in both the G250 and N100 groups prepared integrated reports (KPMG, 2017). In 2017, the biggest number of integrated reports was prepared by the enterprises researched by the KPMG in South Africa (90), Japan (42), Spain (36), Brazil (22) and Mexico (21), while in the European countries - in Poland, Sweden and the UK (15 in each of them) (Figure 2).

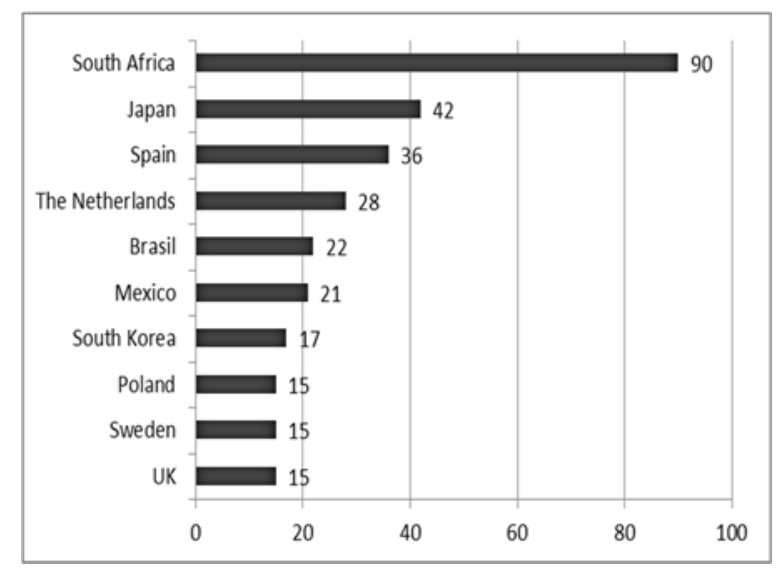

Figure 2. Integrated reporting in top ten countries (source: based on KPMG, 2017)

In Mexico, there has been an increase in the Integrated Reporting, which resulted to some extent from the global growth in the CR reporting integrated reports are considered to be the best practice for giving the sustainability information a strategic character. Investors exert more and more pressure on enterprises to explain the ways in which CSR brings advantage to the business, which supports the requirement for Integrated Reporting. Reporting is becoming an instrument for understanding company value from a long-term perspective rather than a tool whose function is to satisfy regulators (KPMG, 2017).

KPMG research results indicate that the number of companies involved in external assurance of their CSR reporting has increased on a regular basis since 2005. Nowadays, the CSR data assurance commonly adopted in the companies of G250. In the year of 2017, 67 per cent of these companies searched for assurance. When assurance rates among the N100 are lower (currently
45 percent), KPMG forecasts that most N100 companies will have their CR data assured within the coming years if there is no change in the recent tendencies (KMPG, 2017).

The findings of the research study show that the third party-revision of the CSR reports and an efficient internal control have an impact on the role of employees and customers for financial results of the enterprise. Moreover, it is observed that practice of reviewing CSR reports and an effective internal control contribute to the stabilization of financial achievements (Akisin \& Graham, 2017). The relation of given CSR aspects and economic variables is not the same in particular sectors. Scholars show that Oil \& Gas sector, for instance, has the biggest number correlations between external controls and financial performance of all analysed sectors. It might be caused by the fact that such companies sector undergo more external controls (conducted by the government entities and the non-governmental ones) than the others (Blasi, Caporin, \& Fontini, 2018).

\section{The analysis of the contents of the CSR reports in Poland}

The analysis of the development of the CSR reporting in Poland shows that the first report including non-financial data was published in 2005 . In 2011, the number of CSR reports amounted to 34 (including 3 integrated reports); in 2015, there were 55 such reports (including 8 integrated ones); in, 2017, the number increased to 49 (including 15 integrated ones) (Figure 3). Several enterprises prepare the CSR report in a two-year cycle, which is also the cause of the decrease of the report number observed in 2017.

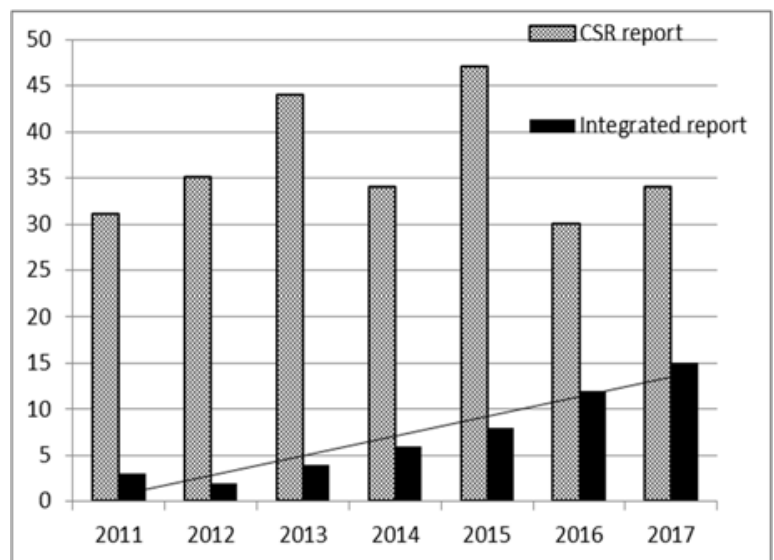

Figure 3. The number of CSR reports and integrated reports published in Poland in the years of 2011-2017 (source: prepared on the basis of Rejestr raportów, 2018) 
There has been a significant increase of integrated report as a tool improving business: in 2011, 3 integrated reports were prepared, while in 2017 - 15. In 2018, there may be significantly more CSR reports published which is related to the obligation of reporting imposed in the Accountancy Act adjusting the requirements of the Directive 2014/09/UE to the Polish regulations. There can be not only integrated reports or social responsibility reports, but also a statement provided with the financial report.

The analysis of the contents of 305 CSR reports of Polish companies conducted from the perspective of implemented reporting tools in the years of 2011-2017 shows that the highest percentage of the researched firms use the GRI guidelines (Figure 4).

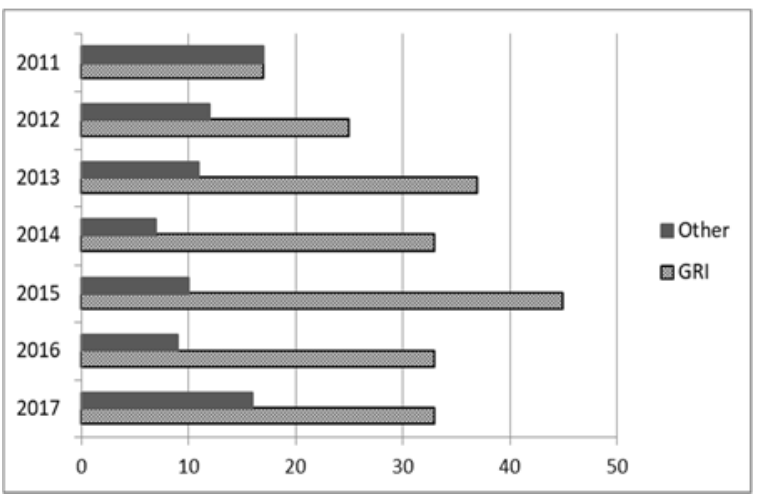

Figure 4. The reporting guidelines used in the Corporate Social Responsibility reporting in Poland in the years of 2011-2017 (source: prepared on the basis of Rejestr raportów, 2018)

The results also attest using other rules, for example ISO26000 or the enterprise own ways of non-financial reporting. Figure 5 shows the share of other guidelines in the reports published in 2017.

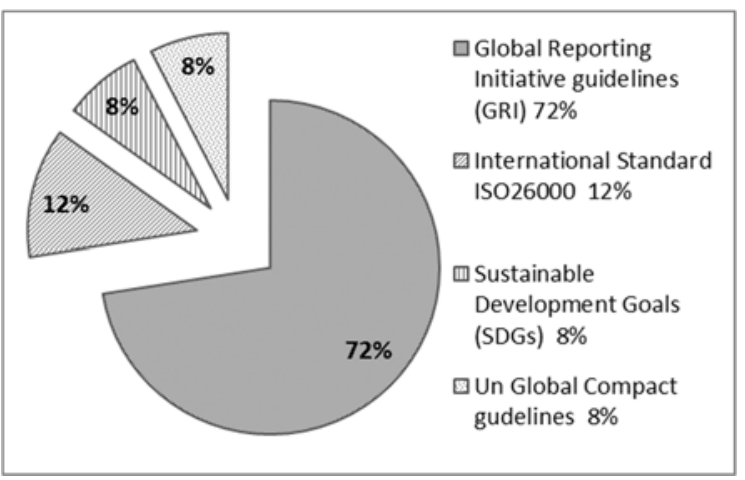

Figure 5. Guidelines used by analyzed companies in Poland in 2017 (source: prepared on the basis of Raporty społeczne, 2018)
Among 40 reports which entered the contest "Raporty społeczne 2017" (lit. Social reports 2017), $72 \%$ were prepared according to the GRI guidelines, while $12 \%$ enterprises used the ISO26000 guidelines. Furthermore, 8\% companies - apart from the reference to the degree of reporting according to GRI - indicate to which other guidelines their activity is adjusted (Un Global or SDGs).

Only two Polish companies presented the information concerning the assurance of their CSR data conducted by the third body. Only one enterprise described the realization of the set aims of development strategy by means of key performance indicators. These aims included lowering the frequency of accidents at work, electricity use and verification of unethical conduct.

\section{Corporate Social Responsibility reporting model}

In the context of key determinants of non-financial reporting development such as increasing and varied stakeholders' expectations concerning information, growing social awareness of business social responsibility, shortage of natural resources, responsibility policy, rapid civilization development as well as globalization and strong competition, a gap is observed in the way of presenting verifiable and credible non-financial information concerning social responsibility of a company as well as in the way of using the reporting results to improve the enterprise activity in the future.

The implementation of the Corporate Social Responsibility reporting model as a tool for improving the enterprise activity begins with the formulation of the activity strategy on the basis of the CSR rules and its realization (Figure 6).

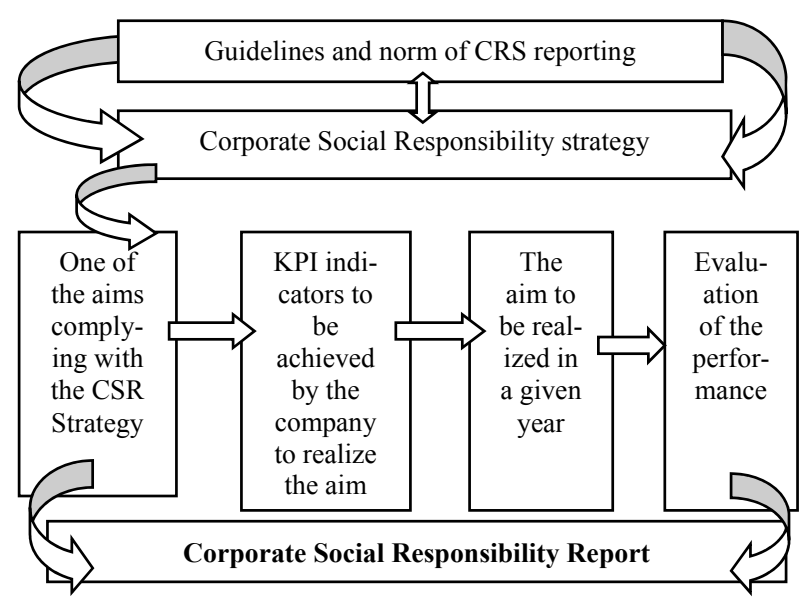

Figure 6. The method of assessment of the CSR activities (source: own elaboration) 
The next step should be to define the specific aims related to the realized strategy. The realization of individual aims ought to be measured by means of key performance indicators (KPIs). KPIs have to be defined in a measurable way. The assumed level of KPIs as the aim to be realized in a given year is verified at the end of the year, which allows for evaluating its performance and undertaking potential remedial actions.

It is highly positive if the results for the previous year and the current one are included, since it facilitates evaluating the enterprise activity by stakeholders.

\section{Conclusion and discussion}

The results of the research study show that the Corporate Social Responsibility reporting is developing dynamically all over the world. However, Europe is not the CSR reporting leader. In Eastern Europe, the CSR reporting rate is by approximately $17 \%$ lower than in Western Europe. In 2017, social reports were prepared by almost all big companies from the G250 group (93\%) and approximately $75 \%$ from 100 biggest companies from the analyzed countries. The growing trend does not result from legislative obligations, since they have been imposed on big companies fairly recently. The causes are is most probably related to two facts: the companies find it benefitial to introduce a CSR-based strategy and the stakeholders' expectations have increased.

Enterprises prepare social reports in various forms: separately, including it in the financial report or preparing an integrated report. The CSR information is very often included in the annual financial report. Over the recent years, the biggest development is observed in the case of the integrated reporting.

In CSR reporting in Poland, one tends to uses the GRI indicators and the ISO 26000 guidelines.

Preparing the Corporate Social Responsibility report as a separate document does not require its combining with financial data. The implementation of the proposed Corporate Social Responsibility reporting model can be a tool for improving the enterprise activity.

To sum up, it can be concluded that more in depth research studies are needed to develop corporate social reporting approaches to address environmental and social challenges more effectively.

\section{References}

AA1000 AccountAbility. (2008). Principles standard (AA1000APS). Retrieved from http://www.accountability.org/standards/

Adamczyk, J. (2013). Raportowanie społecznej odpowiedzialności przedsiębiorstw. Przeglą Organizacji, 4, 8-12.

Akisin, O., \& Graham, G. (2017). The impact of corporate social responsibility and internal controls on stakeholders'view of the firm and financial performance. Sustainability Accounting, Management \& Policy Journal, 8(3), 246-280.

https://doi.org/10.1108/SAMPJ-06-2015-0044

Bagieńska, A. (2017). The activity report as a tool of employer branding. In M. Cingula, M. Przygoda, K. Detelj (Ed.), Economic and Social Development (Book of Proceedings). 23th International Scientific Conference on Economic and Social Development. Madrid.

Basu, K., \& Palazzo, G. (2008). Corporate social responsibility: a process model of sensemaking. The Academy of Management Review, 33(1), 122-136. https://doi.org/10.5465/amr.2008.27745504

Blasi, S., Caporin, M., \& Fontini, F. (2018). A multidimensional analysis of the relationship between corporate social responsibility and firms' economic performance. Ecological Economics, 147, 218-229. https://doi.org/10.1016/j.ecolecon.2018.01.014

Bowen, H. R. (1953). Social responsibilities of the businessman. New York: Harper.

Carrol, A. B. (1979). A three-dimensional conceptual model of corporate performance. Academy of Management Review, 4(4), 497-505. https://doi.org/10.5465/amr.1979.4498296

Cheng, S., Lin, K. Z., \& Wong, W. (2016). Corporate social responsibility reporting and firm performance: evidence from China. Journal of Management and Governance, 20, 503-523. https://doi.org/10.1007/s10997-015-9309-1

Choi, J., \& Wang, H. (2009). Stakeholder relations and the persistence of corporate financial performance. Strategic Management Journal, 39, 895-907. https://doi.org/10.1002/smj.759

Dyrektywa Parlamentu Europejskiego i Rady 2014/95/UE z dnia 22 października 2014 r. zmieniająca dyrektywe 2013/34/UE w odniesieniu do ujawniania informacji niefinansowych $i$ informacji dotyczacych różnorodności przez niektóre duże jednostki oraz grupy (Dz. Urz. UE, L rok 2014, nr 330). Retrieved from https:/eur-lex.europa.eu/legal-content/PL/ TXT/HTML/ ?uri=CELEX:32014L0095\& from $=$ PL

EFFAS. (2014). KPIs for ESG a guideline for the integration of ESG into financial analysis and corporate valuation. The European Federation of Financial Analysts Societies, Frankfurt. Retrieved from http://www.effasesg.com

Feng, M., Wang, X., \& Kreuze, J. G. (2017). Corporate social responsibility and firm financial performance: comparison analyses across industries and CSR categories. American Journal of Business, 32(3), 106-133. https://doi.org/10.1108/AJB-05-2016-0015

Green Paper. (2001). Promoting a European framework for corporate social responsibility. Commission of the $\mathrm{Eu}-$ ropean Communities. Retrieved from https://ec.europa.eu/. 
GRI. (2013). G4 guidelines and ISO 26000: how to use the GRI G4 guidelines and ISO 26000 in conjunction. Retrieved from https://www.iso.org/files/live/sites/isoorg/files/archive/pdf/en/iso-gri-26000_2014-01-28.pdf

Greening, D. W., \& Turban, D. B. (2000). Corporate social performance as a competitive advantage in attracting a quality workforce. Retrieved from http://journals.sagepub.com/doi/pdf/10.1177/000765030003900 302

ISO 26000 and OECD Guidelines Practical overview of the linkages. (2017). Retrieved from https://www.iso. org/files/live/sites/isoorg/files/store/en/PUB100418. pdf

ISO 26000 and the International Integrated Reporting Framework briefing summary. Retrieved from https://www.iso.org/files/live/sites/isoorg/files/archive/pdf/en/iso_26000_and_ir_international_integrated reporting.pdf

Jia, P., Mahdiraji, H. A., Govindan, K., \& Meidutè, I. (2013). Leadership selection in an unlimited three-echelon supply chain. Journal of business economics and management, 14(3), 616-637. https://doi.org/10.3846/16111699.2012.761648

Kendiukhov, I., \& Tvaronavičienè, M. (2017). Managing innovations in sustainable economic growth. Marketing and management of innovations, 3, 33-42. https://doi.org/10.21272/mmi.2017.3-03

Knezevic, B. (2016, May). Corporate social responsibility and consumer ethics from the perspective of young consumers in Croatia. 9th International Scientific Conference Business and Management (pp. 1-11). Vilnius, Lithuania. http://doi.dx.org/10.3846/bm.2016.63

Komarova, V., Lonska, J., Lavrinenko, O., \& Menshikov, V. (2018). Influence of existing social and economic interactions on sustainable territory development: the case of Iceland. Entrepreneurship and Sustainability Issues, 5(3), 412-437. https://doi.org/10.9770/jesi.2018.5.3(1)

KPMG. (2017). The road ahead, the KPMG survey of corporate responsibility reporting. Retrieved from kpmg.com/rreporting

Litfin, T., Meeh-Bunse, G., Luer, K., \& Teckert, O. (2017). Corporate social responsibility reporting - a stakeholder's perspective approach. Business Systems Research, 8(1), 30-42. https://doi.org/10.1515/bsrj-2017-0003

Lulewicz-Sas, A. (2015). Pomiar i ocena społecznie odpowiedzialnej działalnosci przedsiębiorstw - wyniki badań. Prace Naukowe UE we Wrocławiu, 378, 158169. http://doi.dx.org/10.15611/pn.2015.378.12

Maas, K., Schaltegger, S., \& Crutzen, N. (2016). Integrating corporate sustainability assessment, management accounting, control and reporting. Journal of cleaner production, 136, 237-248. https://doi.org/10.1016/j.jclepro.2016.05.008

Mikulska, T., \& Michalczuk, G. (2014). Raportowanie społecznej odpowiedzialności przedsiębiorstwa. Zeszyty Naukowe Uniwersytetu Szczecińskiego, Finanse, Rynki Finansowe, Ubezpieczenia, 69, 209-219.

Pietrzak, M. B., Balcerzak, A. P., Gajdos, A., \& Arendt, L. (2017). Entrepreneurial environment at regional level: the case of Polish path towards sustainable socio-economic development. Entrepreneurship and Sustainability Issues, 5(2), 190-203. https://doi.org/10.9770/jesi.2017.5.2(2)

Raporty społeczne. (2018). CSR reports of Polish companies. Retrieved from www.raportyspoleczne.pl.
Raudeliūnienè, J., Meidutè-Kavaliauskienè, I., \& Vileikis, K. (2016). Evaluation of factors determining the efficiency of knowledge sharing process. Journal of the knowledge economy, 7(4), 842-857. https://doi.org/10.1007/s13132-015-0257-4

Rejestr raportów. (2018). Non financial reports of Polish companies. Retrieved from www.rejestrraportow.pl.

Schaltegger, S., Etxeberria, A. I., \& Ortas, E. (2017). Innovation corporate accounting and reporting for sustainability - attributes and challenges. Sustainable development, 25, 113-122.

Sen, S., Bhattacharya, C. B., \& Korschun, D. (2006). The role of corporate social responsibility in strengthening multiple stakeholder relationships: a field experiment. Journal of the Academy of Marketing Science, 34(2), 158-166. https://doi.org/10.1002/sd.1666

Skrzypek, E. (2010). Etyka w biznesie a społeczna odpowiedzialność przedsiębiorstw. Problemy Jakości, 4, 3-7.

Skrzypek, E. (2015). Społeczna odpowiedzialność i raportowanie. Prace Naukowe Uniwersytetu Ekonomicznego we Wroctawiu, 378, 206-217.

Urbaniec, M. (2015). Raportowanie CSR jako narzędzie doskonalenia działalności biznesowej. Prace Naukowe Uniwersytetu Ekonomicznego we Wrocławiu, 378, 228-242. https://doi.org/10.15611/pn.2015.378.18

Valor, C. (2005). Corporate social responsibility and corporate citizenship: towards corporate accountability. Business and Society Review, 110(2), 191-212. https://doi.org/10.1111/j.0045-3609.2005.00011.x

Wagner, M. (2010). The role of corporate sustainability performance for economic performance: a firm-level analysis of moderation effects. Ecological Economics, 69, $1553-1560$. https://doi.org/10.1016/j.ecolecon.2010.02.017

Wang, S. (2015). Chinese strategic decision-making CSR. Springer. Retrieved from www.springer.com/978-3662-44996-7

Wartick, S., \& Cochran, P. (1985). The evolution of the corporate social performance model. Academy of Management Review, 10(4), 758-769. https://doi.org/10.5465/amr.1985.4279099

Weber, M. (2008). The business case for corporate social responsibility: a company-level measurement approach for CSR. European Management Journal, 26, 247-261. https://doi.org/10.1016/j.emj.2008.01.006

Wołczek, P. (2013). Raportowanie społecznej odpowiedzialności przedsiębiorstw w Polsce. Prace Naukowe Uniwersytetu Ekonomicznego we Wrocławiu, 288, 234-248.

Wróbel, M. (2016). Corporate social responsibility reporting in Poland under regulations directive 2014/95/EU of the European Parliament and of the Council. ZN Wyższej Szkoły Humanitas. Zarzadzanie, 2, 83-94.

Zhao, H., Zhao, F., \& Kwon, J. (2018). Corporate social responsibility research in international business journals: an author co-citation annalysis. International Business Review, 27, 389-400. https://doi.org/10.1016/j.ibusrev.2017.09.006

Zapłata, S., \& Kaźmierczak, M. (2011). Ryzyko, ciagłość biznesu, odpowiedzialność społeczna. Nowoczesne koncepcje zarzadzania. Oficyna Wolters Kluwer business, Warszawa.

Zysnarska-Dworczak, B. (2017). Determinants for development of non-financial reporting and its external verification in the light of accounting theory and practice. Studia Oeconomica Posnaniensia 5(6), 136-149. https://doi.org/10.18559/SOEP.2017.6.8 